\title{
Pendampingan Penulisan Karya Ilmiah Remaja untuk Meningkatkan Kreativitas dan Literasi
}

\author{
Tutut Indria Permana ${ }^{1^{*}}$, Diani Fatmawati ${ }^{2}$ \\ 1,2 Pendidikan Biologi FKIP Universitas Muhammadiyah Malang
}

\section{A R T I C L E I N F O}

Article history:

Received 20 May 2019

Received in revised form 10 June 2019

Accepted 30 July 2019

Available online 30 August 2019

Kata Kunci:

Kreativitas, literasi

penulisan karya ilmiah,

Keywords:

Creativity, literacy, scientific writing

\begin{abstract}
A B S T R A K
Pengabdian ini bertujuan untuk melakukan pendampingan untuk penulisan karya ilmiah remaja pada siswa MA Muhammadiyah 1 Malang. Subjek pengabdian berjumlah 10 orang yang terdiri dari 4 orang guru dan 6 orang siswa. Kegiatan pengabdian dilaksanakan selama 4 bulan. Instrumen untuk mengambil data terdiri dari soal pilihan ganda, soal essay beserta rubrik penilaian, dan kamera untuk dokumentasi. Hasil pengabdian menunjukkan bahwa pemahaman subyek pengabdian terkait metode ilmiah secara umum cukup tinggi (di atas $50 \%$ ). Sedangkan kemampuan berpikir kreatif masih cukup rendah yakni $33 \%$ pada dua indikator ("dapat diterapkan" dan "keterjangkauan biaya") meskipun indikator "kemanfaatan" cukup tinggi (83\%). Pada aspek kemampuan literasi, mayoritas (83\%) subyek pengabdian juga menunjukkan kemampuan pada level paling redah yakni nominal, sedangkan $17 \%$ lainnya pada level fungsional. Berdasarkan hasil pengabdian, maka disarankan untuk memberikan pendampingan dengan frekwensi yang lebih intensif kepada siswa MA Muhammadiyah 1 Malang dengan memberikan fokus yang lebih tegas pada berbagai aspek kemampuan yang masih rendah.
\end{abstract}

\section{A B S T R A C T}

The subjects of this activity were ten people which comprised of four teachers and six students. This community service was conducted for four months. The instruments used to collect the data were contained of multiple choice question sheet, essay questionsheet which was completed with the assessment rubric, and camera to provide pictures data. The results of this community service showed that the subjects' understanding of scientific method was low (33\%) in the two indicators (i.e "applicable" and "affordable") even though the indicator of "usability" was high (83\%). In the literation aspect, the majority (83\%) of subjects indicated the lowest level in term of nominal, while the $17 \%$ remain showed in the functional level. Based on the results obtained, it is suggested to give the more intensive accompaniment to the students' of MA Muhammadiyah 1 Malang by emphasizing the focus on the low level aspects found to be improved.

\footnotetext{
* Corresponding author.

E-mail addresses: tutut.indria@umm.ac.id (Tutut Indria Permana)
} 


\section{Pendahuluan}

Kegiatan pembelajaran terbentuk ketika ada proses interaksi antara pendidik (guru), pebelajar (siswa), dan media pembelajaran (Oyedele, Rwambiwa, \& Mamvuto, 2013). Siswa, secara tidak langsung, dapat secara aktif mengembangkan keterampilan dan pola pikir ketika terjadi kegiatan pembelajaran (Arends, 2012). Kegiatan pembelajaran yang dilakukan harus sesuai dengan perkembangan jaman sekarang di era Revolusi Industri 4.0. Siswa dihadapkan kepada perkembangan teknologi dan ilmu pengetahuan yang sangat pesat, sehingga mereka harus memiliki kemampuan untuk beradaptasi dengan perkembangan tersebut (Agolla, 2018; Aulbur, CJ, \& Bigghe, 2016; Hartmann \& Bovenschulte, 2013; Pfeiffer, 2015).

Adanya perkembangan teknologi dan ilmu pengetahuan menuntut perubahan di dalam sekolah dan proses pembelajaran yang harus berlandaskan prinsip dasar berupa pencapaian simultan antara kualitas (quality) dan kesetaraan (equality) dalam pembelajaran (Sato, 2013). Pembelajaran di era Revolusi Industri 4.0 harus mengakomodasi kemampuan berfikir (Changwong, Sukkamart, \& Sisan, 2018), mengembangkan keterampilan (Osman, Hamid, \& Hassan, 2009), dan pembentukan pola pikir dalam belajar (Ghazivakili et al., 2014). Salah satu kemampuan yang diperlukan oleh siswa untuk menghadapi perkembangan zaman saat ini adalah kreativitas (Adzliana Mohd Daud, Jizah Omar, Punia Turiman, \& Kamisah Osman, 2012; Dole, Bloom, \& Doss, n.d.; Lin \& Wu, 2016; Sherzod Ramankulov et al., 2016; Talat \& Chaudhry, 2014). Kreativitas dan pembelajaran merupakan dua komponen yang saling berkaitan. Mencipta (berkreasi) dan menyusun hal-hal baru juga membutuhkan pengalaman dan pembelajaran baru. Individu terus-menerus belajar dari perasaan, imajinasi, pengalaman dan lingkungan mereka (Zhou, 2012). Selain dalam proses pembelajaran, kreativitas siswa dapat dikembangkan dengan adanya keikutsertaan siswa dalam pembuatan Karya Ilmiah Remaja (KIR).

KIR merupakan salah satu kegiatan ekstrakurikuler yang dapat mewadahi dan mengembangkan kreativitas dan ilmu pengetahuan siswa. Kegiatan ini bertujuan untuk menanamkan sikap ilmiah, kejujuran dalam memecahkan masalah yang ditemui dengan kepekaan yang tinggi dan menggunakan metode yang sistematis untuk mengembangkan diri dalam kehidupan. Dengan demikian adanya KIR bisa menjadikan siswa generasi yang memiliki sikap ilmiah, sehingga mereka mampu untuk memberikan solusi-solusi terhadap masalah yang muncul di sekitar mereka (Sagala, Rahmatsyah, \& Simanjuntak, 2017; Singh, 2009). Selain itu kegiatan analisis masalah yang bersifat ilmiah ini dapat mempengaruhi kemampuan siswa dalam berliterasi (Cook \& Walsh, 2012). Siswa yang memiliki kemampuan literasi memiliki kapasitas untuk menggunakan pengetahuan ilmiah, mengidentifikasi pertanyaan-pertanyaan, menarik kesimpulan berdasarkan bukti-bukti, menjelaskan dan memprediksi fenomena alam dalam rangka mengatasi permasalahan yang berkenaan dengan alam (DeBoer, 2000; PISA, 2015). Secara tidak langung kemampuan siswa berliterasi ini akan berdampak pada pencapaian kompetensi akademik siswa (Lemke et al., 2004).

Namun pada faktanya, tidak semua sekolah mampu membina siswanya untuk bisa menghasilkan karya-karya ilmiah. Seperti halnya pada Madrasah Aliyah (MA) Muhammadiyah 1 Malang, berdasarkan hasil observasi siswa di sekolah ini memiliki banyak prestasi terkait dengan kemampuan berbahasa (Arab dan Bahasa Inggris), olimpade matematika, dan kejuaraan olah raga (pencak silat dan marathon). Fakta ini menunjukkan bahwa ekstrakurikuler terkait dengan KIR masih belum berjalan secara maksimal. Oleh sebab itu perlu dilakukan pendampingan untuk penulisan karya ilmiah remaja pada siswa MA Muhamadiyah 1 Malang.

Hal ini juga didukung oleh visi yang dimiliki oleh MA Muhamadiyah 1 Malang yakni menjadi madrasah yang unggul dalam sains dengan dasar bahasa Arab, bahasa Inggris, serta berketerampilan. Untuk merealisasikan visi sekolah dijabarkan 7 (tujuh) misi sekolah, yaitu: (1) memupuk minat dan bakat siswa, sehingga setiap siswa dapat berkembang sesuai dengan proses yang dimiliki; (2) membentuk siswa berakhlakul karimah; (3) menciptakan lingkungan bersih dan agamis; (4) membentuk pola piker kritis dan ilmiah; (5) menumbuhkan dan menjaga sikap disiplin serta bertanggungjawab dalam bermasyarakat; (6) menciptakan suasana belajar siswa aktif dengan berbasis IT; dan (7) meningkatkan keterampilan dan kemampuan berbahasa Inggris dan bahasa Arab. Pembuatan karya ilmiah oleh siswa ini sangat erat kaitannya dengan misi poin empat (4). Dengan demikian pendampingan dan keberlanjutan dari kemampuan siswa untuk melahirkan hasil olah piker berupa karya-karya ilmiah ini sangat perlu untuk dilakukan. Adapun bentuk pendampingan yang dilakukan adalah memberikan pengenalan dan implementasi cara menyusun suatu karya ilmiah yang sesuai dengan metode ilmiah untuk meningkatkan prestasi, kreativitas dan literasi siswa MA Muhammadiyah I Malang. 


\section{Metode}

Pengabdian dilakukan di sekolah mitra yaitu MA Muhammadiyah 1 Malang. Permasalahan pada sekolah mitra berkaitan dengan pentingnya daya berpikir kreatif dan kemampuan berliterasi yang yang perlu dikembangkan. Salah satu upaya yang dilakukan adalah dengan kegiatan pendampingan kepada para guru dan siswa dalam penulisan karya ilmiah. Partisipasi yang diberikan mitra dalam pelaksanaan program pengabdian ini adalah: 1) Menyediakan sumber daya manusia, yaitu para guru dan siswa dari berbagai mata pelajaran untuk menjadi peserta pendampingan penulisan karya ilmiah; 2) Menyediakan tempat dan ruang yang representatif untuk kelancaran pelaksanaan kegiatan pengabdian.

Subjek pengabdian berjumlah 10 orang yang terdiri dari 4 orang guru dan 6 orang siswa. Kegiatan pengabdian dilaksanakan selama 3.5 bulan. Instrumen untuk mengambil data terdiri dari soal pilihan ganda, soal essay beserta rubrik penilaian, dan kamera. Soal pilihan ganda berisi tentang pengetahuan metode ilmiah yang terdiri 15 item untuk mengukur kemampuan subjek dalam memahami dan menganalisis metode ilmiah, indicator soal dapat dilihat pada Tabel 1. Soal essay beserta rubrik penilaian digunakan untuk menentukan kreativitas dan kemampuan literasi subjek. Indikator kreativitas dilihat dari 3 aspek, yakni: (1) dapat diterapkan, (2) kemanfaatan, dan (3) keterjangkauan biaya (Wilson, 2019). Tingkatan (level) literasi dari yang terendah hingga paling tinggi berturut-turut adalah nominal, fungsional, struktural, dan multidimensional (Birzina, 2011). Kamera digunakan untuk melakukan dokumentasi ketika proses pengabdian berlangsung. Metode pelaksanaan pengabdian yang telah didiskusikan dan disepakati bersama dengan sekolah mitra disajikan dalam Tabel 2 .

Tabel 1. Indikator item soal untuk mengukur kemampuan memahami dan menganalisis metode ilmiah

\begin{tabular}{ccc}
\hline Kode & Indikator yang diukur & Nomor urut soal \\
\hline A & Memahami jenis data & 1 \\
B & Menentukan tujuan penelitian & 2,3 \\
C & Mengidentifikasi komponen karya ilmiah & $4,6,14,15$ \\
D & Merumuskan judul karya ilmiah & 5,8 \\
E & Memahami komponen metode penelitian & $7,9,10,13$ \\
F & Memilih pustaka yang relevan & 11,12 \\
\hline
\end{tabular}

Tabel 2. Metode pelaksanaan pengabdian di MA Muhammadiyah 1 Malang

\begin{tabular}{|c|c|c|c|}
\hline 0 & $\begin{array}{ll}\text { Langkah } & \text { Kegiatan } \\
\text { Pengabdian } & \\
\end{array}$ & Deskripsi Kegiatan & Metode \\
\hline & $\begin{array}{l}\text { Sosialisasi program } \\
\text { pengabdian dengan } \\
\text { pihak sekolah mitra } \\
\text { (MA Muhammadiyah } \\
\text { I Malang) }\end{array}$ & $\begin{array}{l}\text { a. Merancang kegiatan yang akan dilaksanakan dalam } \\
\text { kurun waktu } 4 \text { bulan. } \\
\text { b. Membuat kesepakatan jadwal pelaksanaan } \\
\text { pendampingan } \\
\text { c. Melakukan pembagian tugas (job description) pada } \\
\text { masing-masing pihak, yaitu tim pengabdi, guru } \\
\text { yang bertindak sebagai guru pendamping dan } \\
\text { siswa kelas X dan XI IPA. }\end{array}$ & $\begin{array}{l}\text { Diskusi } \\
\text { Diskusi } \\
\text { Diskusi }\end{array}$ \\
\hline & $\begin{array}{lr}\text { Pelatihan } & \text { dan } \\
\text { pendampingan } & \\
\text { pembuatan } & \text { karya } \\
\text { ilmiah } & \end{array}$ & $\begin{array}{l}\text { a. Penggalian kemampuan awal guru dan siswa } \\
\text { sebagai subjek pengabdian } \\
\text { b. Penggalian ide dan minat penelitian } \\
\text { c. Menyusun desain peneltiian } \\
\text { d. Menyusun proposal penelitian }\end{array}$ & $\begin{array}{l}\text { Tes \& diskusi } \\
\text { interaktif } \\
\text { Studi literature } \\
\text { \& diskusi } \\
\text { Diskusi } \\
\text { Penugasan, } \\
\text { studi literatur \& } \\
\text { diskusi } \\
\end{array}$ \\
\hline
\end{tabular}

\section{Hasil dan pembahasan}

Sosialisasi Program Pengabdian dengan Pihak Sekolah Mitra

Kegiatan sosialisasi program pengabdian dengan pihak sekolah mitra dilaksanakan pada hari Sabtu 27 April 2019. Kegiatan sosialisasi ini dilaksanakan tim pengabdi untuk merancang kegiatan yang akan dilaksanakan dalam kurun waktu 3.5 bulan. Pada tahap ini disepakati jadwal pelaksanaan pendampingan dan pembagian tugas (job description) pada masing-masing pihak, yaitu tim pengabdi, guru yang 
bertindak sebagai guru pendamping dan siswa kelas X dan XI. Adapun job description dimaksud sebagai berikut: 1) Tugas pengabdi meliputi: 1) sebagai fasilitator dalam pengembangan karya ilmiah; 2) melakukan pendampingan dan memberi evaluasi terhadap karya ilmiah yang disusun oleh siswa yang didampingi oleh guru, 2) Tugas guru pendamping adalah sebagai pemimbing bagi siswa untuk memberikan arahan terhadap karya ilmiah yang disusun, dan 3) Tugas siswa adalah sebagai pelaksana dalam pengembangan karya ilmiah dengan kolaborasi bersama teman sebaya.

Pelatihan dan Pendampingan Pembuatan Karya Ilmiah

Kegiatan dilaksanakan bulan Mei-Agustus 2019 dengan ruangan dan waktu yang berubah-ubah sesuai dengan kondisi sekolah. Hasil tes untuk menggali kemampuan awal guru dan siswa terkait bagaimana mereka memahami dan menganalisis metode ilmiah ditampilkan pada Gambar 1. Gambar 1 menunjukkan bahwa tingkat pemahaman subyek mengabdian tentang karya ilmiah secara umum sudah tinggi. Hal ini terbukti dengan tingginya presentase seluruh indikator yakni di atas $50 \%$. Secara lebih detail, pemahaman dengan persentase tertinggi adalah pada indikator D yakni "Merumuskan judul karya ilmiah" yang mencapai 95\% yang disusul dengan indikator F yakni "Memilih pustaka yang relevan" (90\%). Sebaliknya, pemahaman terendah dari subyek pengabdian adalah pada indikator C ("Mengidentifikasi komponen karya ilmiah") yang hanya mencapai 57,5\%. Selebihnya, dua indikator lain yakni B ("Menentukan tujuan penelitian") dan E ("Memahami komponen metode penelitian") mencapai persentase 60 dan 72.5 secara berturut-turut. Dokumentasi kegiatan dapat dilihat pada Gambar 2.

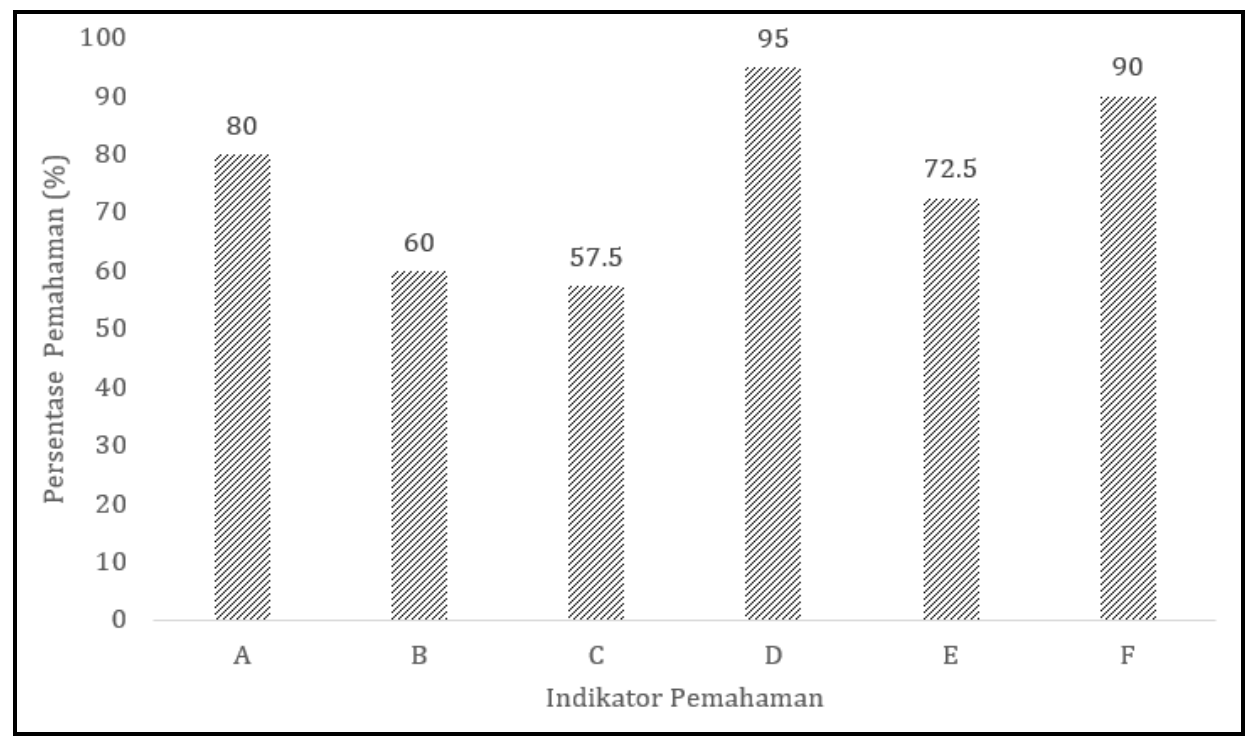

Gambar 1. Hasil tes penggalian kemampuan awal guru dan siswa terkait metode penelitian, keterangan indikator dijelaskan pada Tabel 1.

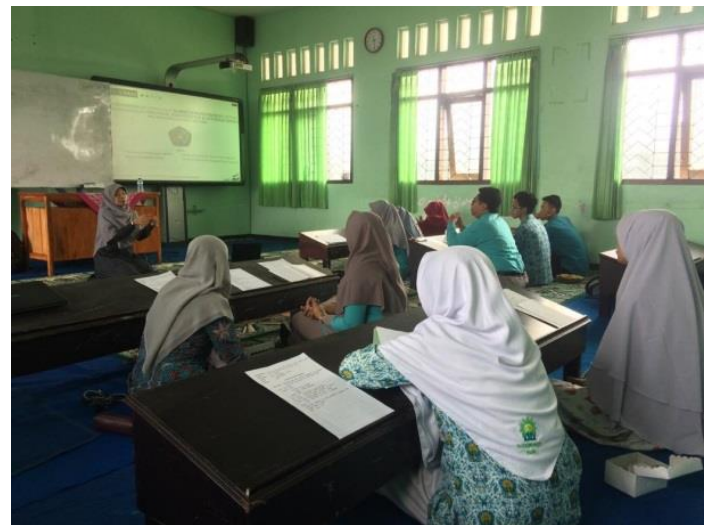

(a)

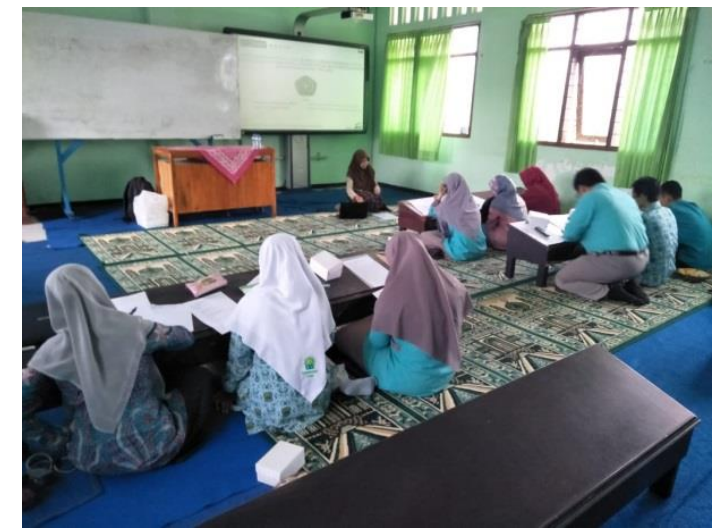

(b)

Gambar 2. Dokumentasi kegiatan penggalian kemampuan awal guru dan siswa terkait pemhaman metode ilmiah, (a) kegiatan diskusi dan (b) siswa dan guru mengerjakan soal tes. 
Selanjutnya hasil tes essay untuk menentukan kreativitas dicantumkan pada Gambar 3 yang menjelaskan bahwa pada ide-ide penelitian yang dimunculkan oleh siswa paling tinggi pada indikator kemanfaatan (83\%), sedangkan pada dua indikator lainnya (dapat diterapkan dan keterjangkauan biaya) memperoleh nilai persentase yang sama, yaitu 33\%. Selanjutnya hasil pengukuran kemampuan literasi siswa (dicantumkan pada Gambar 4) menunjukkan bahwa 83\% siswa masih berada pada tingkat paling rendah, yaitu level nominal. Sedangkan sisanya (17\%) berada pada tingkat fungsional.

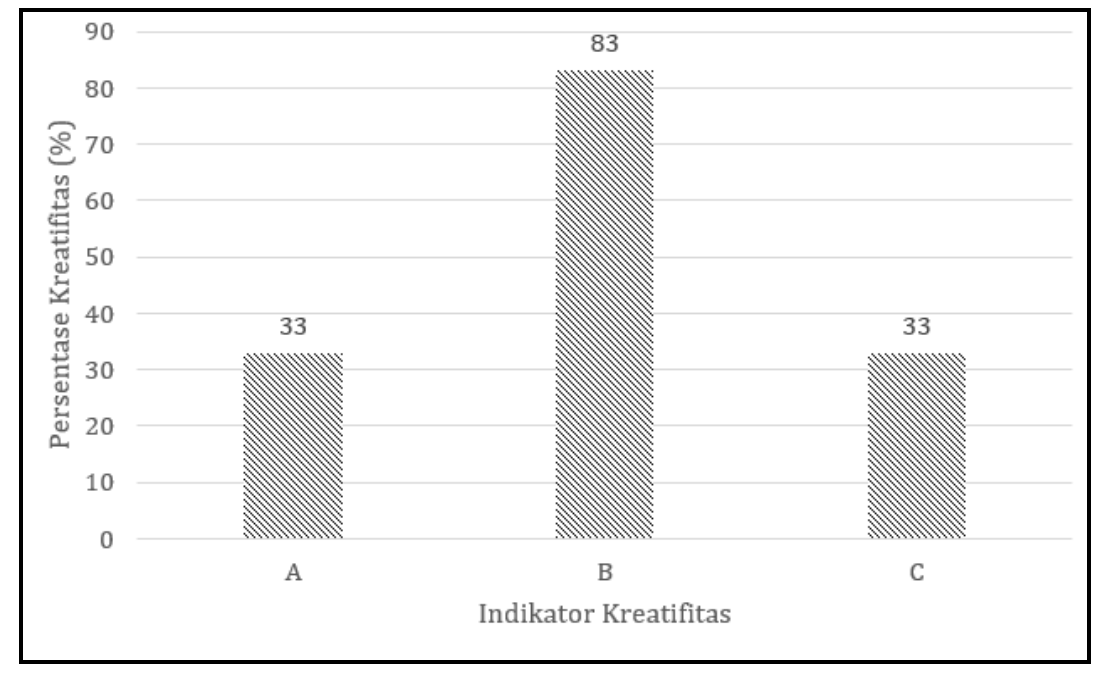

Gambar 3. Hasil pengukuran kreativitas siswa yang dilihat dari indikator: dapat diterapkan (A), kemanfaatan (B), dan keterjangkauan biaya (C).

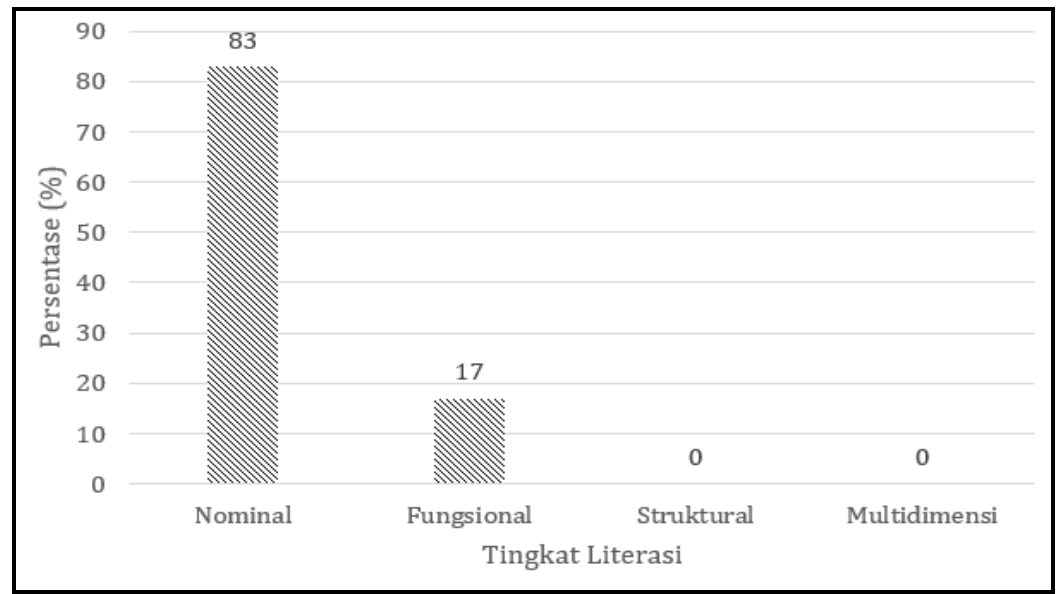

Gambar 4. Hasil pengukuran kemampuan literasi siswa.

Hasil pengabdian menunjukkan bahwa subjek pengabdian sudah memiliki pemahaman tentang karya ilmiah yang secara umum sudah tinggi. Hal ini terbukti dengan tingginya presentase seluruh indikator yakni di atas 50\% (Gambar 1). Secara lebih detail, pemahaman dengan persentase tertinggi adalah pada indikator "Merumuskan judul karya ilmiah" (95\%) dan "Memilih pustaka yang relevan" (90\%). Hal ini menunjukkan bahwa guru dan siswa sudah memiliki pengalaman dalam merumuskan judul dan menentukan sumber-sumber yang relevan. Berdasarkan hasil wawancara, siswa yang menjadi subjek pengabdian merupakan siswa yang memiliki kemampuan akademik tinggi dan sebagian siswa sudah pernah mengikuti kegiatan KIR. Dengan demikian siswa sudah terbiasa untuk mencari informasiinformasi yang relevan untuk dijadikan sumber pustaka. Seperti dijelaskan oleh Shephard (2008) bahwa pengalaman yang dimiliki oleh siswa akan berdampak pada keterampilannya, dalam hal ini adalah mencari sumber bacaan yang relevan.

Sebaliknya, pemahaman terendah dari subyek pengabdian adalah pada indikator "Mengidentifikasi komponen karya ilmiah" yang hanya mencapai 57,5\%. Pada indikator ini menunjukkan bahwa siswa masih kesulitan dalam mengidentifikasi komponen karya ilmiah, seperti latar belakang, rumusan masalah, hipotesis, metode, hasil, dan pembahasan. Hal ini terjadi karena siswa tidak terbiasa melakukan kegiatan 
pembelajaran dengan menerapkan metode ilmiah. Menurut Erkol dan Ugulu (2014) metode ilmiah merupakan faktor penting untuk memberikan keterampilan proses ilmiah. Keterampilan ini berperan untuk melatih mereka dalam meneliti, mengamati dan mampu beradaptasi dengan perkembangan zaman. Sehingga siswa mampu memecahkan masalah yang mereka hadapi di lingkungan sekitar mereka. Dengan demikian sekolah harus menjadi tempat yang mewadahi siswa untuk mengasah keterampilan proses ilmiahnya, baik melalui pembelajaran kurikuler maupun ekstrakurikuler. Dalam kegiatan ekstrakurikuler, KIR menjadi salah satu wadah utama yang melatih siswa berpikir secara ilmiah. Siswa yang terbiasa dengan prosedur-prosedur ilmiah akan lebih mampu bertahan dalam menghadapi tantangan perubahan zaman di Abad 21 ini (Osman et al., 2009; Talat \& Chaudhry, 2014; Turiman, Omar, Daud, \& Osman, 2012).

Selanjutnya hasil pengabdian terhadap kreativitas siswa menunjukkan bahwa $83 \%$ siswa mampu memunculkan ide-ide yang memiliki nilai kemanfaatan. Namun hanya 33\% siswa saja yang mampu menciptakan ide dengan memperhatikan dapat diterapkannya ide tersebut dan keterjangkauan biaya untuk mewujudkan ide tersebut. Hal ini menunjukkan kreativitas siswa masih perlu ditingkatkan lagi, baik dengan pembinaan oleh guru pedamping atau tim pengabdi. Menurut beberapa penelitian sebelumnya kreativitas tidak bisa dimunculkan tanpa adanya perlakuan pada siswa. Perlakuan yang dimaksud bisa berupa pengalaman belajar yang diberikan kepada siswa yang dapat memacu mereka untuk mengeluarkan ide-ide kreatifnya, seperti penerapan pembelajaran berbasis masalah (Talat \& Chaudhry, 2014; Zhou, 2012), pembelajaran berbasis proyek (Sookpatdhe \& Soranastaporn, 2016; Zhou, 2012), atau pembelajaran kooperatif (Gunawan, A Harjono, H Sahidu, \& Nisrina, 2018). Hasil pengabdian dalam pendampingan KIR harus didukung juga dengan peningkatan proses pembelajaran di kelas dengan menerapkan berbagai macam model pembelajaran yang dapat memacu kreativitas siswa.

Fakta yang masih sangat kurang dari hasil pengabdian ini adalah upaya peningkatan literasi siswa. Hasil pengabdian menunjukkan bahwa siswa bahwa 83\% siswa masih berada pada tingkat paling rendah, yaitu level nominal, dan sisanya (17\%) berada pada tingkat fungsional (Gambar 4). Kemampuan literasi siswa belum mencapai level struktural dan multidimensi. Hal ini bisa terjadi dikarenakan waktu pengabdian yang kurang lama dan kurang intensifnya diskusi dalam proses pengabdian. Siswa masih cenderung malu-malu untuk bertanya kepada tim pengabdi sehingga tim pengabdi tidak bisa benar-benar mengakses kemampuan literasi mereka. Selain itu siswa masih cenderung pasif untuk mengungkapkan masalah yang ditemukan selama proses penyusunan KIR. Disisi lain siswa masih harus mengikuti kegiatan kurikuler sekolah yang cukup padat, sehingga mereka tidak benar-benar fokus pada kegiatan menyusun KIR. Hal ini juga bisa dikaitkan dengan motivasi siswa yang masih rendah dalam melakukan penyelidikan ilmiah. Menurut Turner (1995) motivasi mencari informasi akan mempengaruhi tingkat literasi siswa. Dengan demikian siswa masih perlu untuk didorong agar mereka lebih termotivasi dalam melakukan kegiatan-kegiatan yang melatih mereka berpikir secara ilmiah, salah satunya dengan keikutsertaan dalam kegiatan penulisan KIR.

\section{Simpulan dan saran}

Berdasarkan kegiatan pengabdian yang telah dilakukan, maka dapat disimpulkan beberapa poin terkait dengan kemampuan subyek pengabdian dalam menyusun karya ilmiah. Pertama, secara umum, pemahaman awal yang dimiliki oleh subyek pengabdian terkait metode ilmiah cukup tinggi (di atas 50\%). Kedua, kemampuan berpikir kreatif masih rendah yang dibuktikan dengan rendahnya persentase dua dari tiga indikator yang diukur (33\%), meskipun satu indikator lainnya mencapai 83\%. Ketiga, kemampuan literasi sebagian besar (83\%) subyek pengabdian masih berada pada tingkat terendah yakni tingkat nominal, dimana 17\% lainnya juga masih mencapai tingkat fungsional. Dengan demikian dapat disarankan bagi pihak sekolah untuk mengarahkan pembinaan penulisan karya ilmiah bagi siswa MA Muhammadiyah 1 Malang lebih intensif pada berbagai aspek yang masih rendah dan perlu ditingkatkan.

\section{Daftar Rujukan}

Adzliana Mohd Daud, Jizah Omar, Punia Turiman, \& Kamisah Osman. (2012). Creativity in science education. Procedia - Social and Behavioral Sciences, 59, 467 - 474. https://doi.org/10.1016/j.sbspro.2012.09.302

Agolla, J. E. (2018). Human capital in the smart manufacturing and industry 4.0 revolution. In A. Petrillo, R. Cioffi, \& F. De Felice (Eds.), Digital Transformation in Smart Manufacturing (pp. 41-58). https://doi.org/10.5772/intechopen.73575 
Arends, R. I. (2012). Learning to teach (9th ed.). Retrieved from http://onlinelibrary.wiley.com/doi/10.1002/cbdv.200490137/abstract

Aulbur, W., CJ, A., \& Bigghe, R. (2016). Skill development for Industry 4.0. India: Roland Berger. Retrieved from http://www.globalskillsummit.com/whitepaper-summary.pdf

Birzina, R. (2011). Biology students' comprehension of learning as a development of their biologycal literacy. In Scientific Papers University of Latvia, Vol. 778 . Retrieved from https://www.researchgate.net/publication/269101031_Biology_students'_comprehension_of_lear ning_as_a_development_of_their_biological_literacy

Changwong, K., Sukkamart, A., \& Sisan, B. (2018). Critical thinking skill development: Analysis of a new learning management model for Thai high schools. Journal of International Studies, 11(2), 37-48. https://doi.org/10.14254/2071

Cook, P., \& Walsh, M. (2012). Collaboration and problem-based learning: Integrating information literacy into a political science. Communications in Information Literacy, 6(1), 59-72. Retrieved from http://www.comminfolit.org/index.php?journal=cil\&page=article\&op=view\&path\%5B\%5D=v6i1p 59

DeBoer, G. E. (2000). Scientific literacy: Another look at its historical and contemporary meanings and its relationship to science education reform. Journal of Research in Science Teaching, 37(6), 582-601. https://doi.org/10.1002/1098-2736(200008)37:6<582::AID-TEA5>3.0.C0;2-L

Dole, S. F., Bloom, L. A., \& Doss, K. K. (n.d.). Rocket to creativity: A field experience in problem-based and project-based learning. Retrieved from https://files.eric.ed.gov/fulltext/EJ1120599.pdf

Erkol, S., \& Ugulu, I. (2014). Examining Biology Teachers Candidates ' Scientific Process Skill Levels and Comparing These Levels in Terms of Various Variables. In 5th World Conference on Educational Sciences - WCES 2013 Examining (Vol. 116, pp. 4742-4747). Elsevier B.V. https://doi.org/10.1016/j.sbspro.2014.01.1019

Ghazivakili, Z., Norouzi Nia, R., Panahi, F., Karimi, M., Gholsorkhi, H., \& Ahmadi, Z. (2014). The role of critical thinking skills and learning styles of university students in their academic performance. Journal of Advances in Medical Education \& Professionalism, 2(3), 95-102. Retrieved from https://www.ncbi.nlm.nih.gov/pmc/articles/PMC4235550/

Gunawan, A Harjono, H Sahidu, \& Nisrina. (2018). Improving students' creativity using cooperative learning with virtual media on static fluida concept. In International Conference on Science Education (ICoSEd) . IOP Publishing. https://doi.org/10.1088/1742-6596/1006/1/012016

Hartmann, E. A., \& Bovenschulte, M. (2013). Skills needs analysis for "Industry 4.0" based on roadmaps for smart systems. In SKOLKOVO (Ed.), Using Technology Foresights for Identifying Future Skills Needs. Global Workshop Proceedings (pp. 24-36). Moscow. Retrieved from https://www.iitberlin.de/de/publikationen/skills-needs-analysis-for-industry-4-0201d-based-on-roadmaps-forsmart-systems/at_download/download

Lemke, M., Sen, A., Pahlke, E., Partelow, L., Miller, D., Williams, T., ... Jocelyn, L. (2004). International Outcomes of Learning in Mathematics Literacy and Problem Solving: PISA 2003 Results From the U.S. Perspective. Highlights. NCES 2005-003. US Department of Education. Retrieved from http://eric.ed.gov/?id=ED484183

Lin, C.-S., \& Wu, R. Y.-W. (2016). Effects of web-based creative thinking teaching on students' creativity and Learning Outcome. EURASIA Journal of Mathematics, Science \& Technology Education, 12(6), 1675-1684. https://doi.org/10.12973/eurasia.2016.1558a

Osman, K., Hamid, S. H. A., \& Hassan, A. (2009). Standard setting: Inserting domain of the 21st century thinking skills into the existing science curriculum in Malaysia. Procedia - Social and Behavioral Sciences, 1(1), 2573-2577. https://doi.org/10.1016/j.sbspro.2009.01.454 
Oyedele, V., Rwambiwa, J., \& Mamvuto, A. (2013). Using educational media and technology in teaching and learning processes: A case of trainee teachers at Africa University. Academic Research International, 4(1). Retrieved from http://www.savap.org.pk/journals/ARInt./Vol.4(1)/2013(4.1-30).pdf

Pfeiffer, S. (2015). Effects of Industry 4.0 on vocational education and training. (I. of T. A. (ITA), Ed.). Vienna: Austrian Academy of Sciences (ÖAW). Retrieved from http://epub.oeaw.ac.at/ita/itamanuscript/ita_15_04.pdf

PISA. (2015). Draft science framework. Retrieved from https://www.oecd.org/pisa/pisaproducts/Draft PISA 2015 Science Framework .pdf

Sagala, N. L., Rahmatsyah, \& Simanjuntak, M. P. (2017). The influence of problem based learning model on scientific process skill and problem solving ability of student. IOSR Journal of Research \& Method in Education, 7(4), 1-9. https://doi.org/10.9790/7388-0704040109

Sato, M. (2013). Mereformasi sekolah-Konsep dan praktek komunitas belajar. PELITA/IDCJ.

Shephard, K. (2008). Higher education for sustainability: seeking affective learning outcomes. International Journal of Sustainability in Higher Education, 9(1), 87-98. https://doi.org/10.1108/14676370810842201

Sherzod Ramankulov, Indira Usembaeva, Dinara Berdi, Bakhitzhan Omarov, Bagdat Baimukhanbetov, \& Nurdaulet Shektibayev. (2016). Formation of the creativity of students in the context of the education informatization. International Journal of Environmental \& Science Education, 11(16), 9598-9613. Retrieved from http://creativecommons.org/licenses/by/4.0/

Singh, C. (2009). Problem solving and learning. In AIP Conference Proceedings (Vol. 1140, pp. 183-197).

Sookpatdhe, T., \& Soranastaporn, S. (2016). Simulation and project based learning for developing creativity: From classroom to real life. ThaiSim Journal: Learning Development (TSJLD), 1(1), 85105. Retrieved from http://www.thaisim.org/sgld/

Talat, A., \& Chaudhry, H. F. (2014). The effect of PBL and 21st century skills on students' creativity and competitiveness in private schools. The Lahore Journal of Business, 2(2), 89-114. Retrieved from http://www.lahoreschoolofeconomics.edu.pk/businessjournals/V2issue2/05 Talat and Chaudhry FINAL.pdf

Turiman, P., Omar, J., Daud, A. M., \& Osman, K. (2012). Fostering the 21st century skills through scientific literacy and science process skills. Procedia - Social and Behavioral Sciences, 59, 110-116. https://doi.org/10.1016/j.sbspro.2012.09.253

Turner, J. C. (1995). The influence of classroom contexts on young children's motivation for literacy. Reading Research Quarterly, 30(3), 410-441. https://doi.org/10.2307/747624

Wilson, L. 0. (2019). Criteria to help evaluate creative ideas. Retrieved August 15, 2019, from https://thesecondprinciple.com/creativity/criteria-to-help-evaluate-creative-ideas/

Zhou, C. (2012). Integrating creativity training into problem and project-based learning curriculum in engineering education. European Journal of Engineering Education, 37(5), 488-499. https://doi.org/10.1080/03043797.2012.714357 